DOI: 10.32844/2222-5374-2020-104-2.43

УДК: 343.122 (477)

\author{
Мартовицька О. В., \\ доцент кафедри кримінального процесу та організації \\ досудового слідства Харківського національного \\ університету внутрішніх справ, \\ кандидат юридичних наук
}

\title{
ПОНЯТТЯ ТА КРИТЕРІЇ КЛАСИФІКАЦІЇ ЗАСАД НАДАННЯ ТА РЕАЛІЗАЦІЇ ПРАВОВОЇ ДОПОМОГИ
}

Актуальність статті полягає в тому, що належне надання правової допомоги йу подальшому ефективна реалізація їі окремих процедур напряму залежить від повноти й якості визначення провідних засад функціонування даної сфери суспільних відносин. Саме засади надання та реалізації правової допомоги мають визначальний вплив на подальший розвиток даних суспільних відносин, оскільки їх недотримання або ж порушення може поставити під сумнів законність та обгрунтованість кінцевих процесуальних рішень. У статті наголошено на необхідності з'ясування сутності та критеріїв класифікації засад надання та реалізації правової допомоги з урахуванням як наукових напрацювань, так і нормативноправових положень зметою визначити теоретичні та прикладні проблеми інституту професійної правничої допомоги в кримінальному процесі України. Підкреслено, що засади надання та реалізацї правової допомоги мають визначальний вплив на подальший розвиток даних суспільних відносин, оскільки їх недотримання або ж порушення може поставити під сумнів законність та обгрунтованість кінцевих процесуальних рішень. Уточнено понятійно-категоріальний апарат, що використовується в представленому дослідженні. З'ясовано, що актуальним є використання вузького підходу до визначення сутності категорії «засада», в досліджуваному випадку - їх ототожнення з категорією «принцип». Запропоновано під засадами надання та реалізації правової допомоги розуміти закріплену в приписах чинного національного законодавства сукупність правових положень, на основі яких уповноважені суб'єкти надають правову допомогу, що в подальшому реалізується в межах функціонування відповідних суспільних відносин. Зазначено, що на сьогодні можна назвати доволі значну кількість засад надання та реалізації правової допомоги, з огляду на що їх слід піддати науковій класифікації. Сформовано критерії класифікації засад надання та реалізащії правової допомоги можуть з огляду на значну кількість аспектів: сфери суспільних відносин; правових засад їх функціонування; суб'єктного складу; процесуальної стадї тощо. Надано пропозищію обрати найбільш універсальний критерій класифікації засад надання й реалізації правової допомоги, який би вказував як на загальне значення даної інституції, так і на особливості їі функціонування в межах кримінального процесу Украӥни. 
Ключові слова: принципи, засади, правова допомога, надання, реалізація, класифікація.

Актуальність теми. Належне надання правової допомоги й $\mathrm{y}$ подальшомуефективнареалізаціяіїокремихпроцедурнапрямузалежитьвід повноти й якості визначення провідних засад функціонування даної сфери суспільних відносин. Саме засади надання та реалізації правової допомоги мають визначальний вплив на подальший розвиток даних суспільних відносин, оскільки їх недотримання або ж порушення може поставити під сумнів законність та обгрунтованість кінцевих процесуальних рішень. Ось чому в аспекті дослідження теоретичних і прикладних проблем інституту професійної правничої допомоги в кримінальному процесі України вкрай важливого значення набуває питання щодо визначення сутності засад правового допомоги взагалі й аналізу окремих з них зокрема.

Аналіз останніх досліджень. Інститут правової допомоги та права на неї неодноразово досліджували в своїх працях такі вчені, як: О.А. Банчук, Є.Ю. Бова, Г.І. Гладун, М.С. Демкова, В.В. Заботін, В.М. Ісакова, С.С. Калинюк, M.В. Кравченко, M.I. Лахижа, В.С. Личко, М.T. Лоджук, М.I. Рішко, М.В. Стаматіна, Н.В. Хмелевська, Ю.Т. Шрамко й інші. Разом із тим чимало питань по сьогоднішній день залишаються дискусійними. Зокрема, 3 урахуванням постійного оновлення вітчизняного законодавства багато наукових напрацювань про правову допомогу втратили свою актуальність. Тому метою представленої статті $€$ визначення поняття засад надання та реалізації правової допомоги, а також виокремлення критеріїв їх класифікації.

Виклад основного матеріалу. Відправною точкою вирішення поставленого наукового завдання слід обрати уточнення понятійнокатегоріального апарату, що використовується в представленому дослідження, зокрема сутності такої категорії як власне «засада». 3 точки зору семантики, дану категорію доволі часто використовують як синонімічну категорії «принцип». Зокрема, авторський колектив великого тлумачного словника зазначає, що під словом «засада» слід розуміти: основу чогось; те головне, на чому грунтується, базується що-небудь; вихідне головне положення, принцип; основа світогляду, правило поведінки. У свою чергу, сутність слова «принцип» тлумачать у наступних значеннях: основне вихідне положення якої-небудь наукової системи, теорії, ідеологічного напряму тощо; особливість, покладена в основу створення або здійснення чого-небудь, спосіб створення або здійснення чогось, правило, покладено в основу діяльності якої-небудь організації, товариства тощо; переконання, норма, правило, яким керується хто-небудь у житті, поведінці $[1$, с. 419, 1125]. У цьому контексті цілком слушною є позиція 0.3. Хотинської, відповідно до якої з філологічної точки зору, терміни «принцип» та «засада» є синонімами. Поряд 3 ними в цьому синонімічному ряді стоїть термін «основи» [2, с. 18].

В юридичній енциклопедичній літературі сутність категорії «принцип» також визначають через категорію «засада». Наприклад, зазначається, що принципом $€$ основні універсальні фундаментальні положення, які покладаються в основу галузі та $\epsilon$ підставою для формування та функціонування її системи й змісту і слугують засадами 
для регулювання відповідних правовідносин [3, с. 736]. Тобто в більшості випадків, сутність засад визначають через принципи й навпаки.

Окремі 3 учених-правознавців наголошують на відмінностях досліджуваних категорій, вказуючи при цьому на більш широкий зміст категорії «засади». Наприклад, стверджується, що «принцип» ближчий до поняття «правило», а «засада» - це, швидше, більш загальне поняття, яке вказує на належність до якогось соціально-правового явища. Засада втрачає значення тільки принципу і розуміється ширше [4, с. 23-24; 5, с. 16]. Аналізуючи зміст категорії «правові засади», В.Б. Пчелін стверджує, що можна назвати як мінімум два підходи до її розуміння. Так, більш широкий підхід до іï розуміння передбачає включення до її змісту як основ нормативноправового регулювання відповідної сфери суспільних відносин, так й інші їх структурні елементи (систему суб'єктів, основи їх правового статусу, тощо). У другому випадку мова йде про вузьке розуміння правових засад як виключно нормативних основ. Такий підхід до розуміння «правових засад» $є$ найбільш поширеним у правовій науці [6, с. 108; 7, с. 53-64]. Із чого слідує, що актуальним $є$ використання вузького підходу до визначення сутності категорії «засада», в досліджуваному випадку - їх ототожнення з категорією «принцип». При цьому розкриття сутності останньої буде корисним в аспекті повного та всебічного визначення сутності засад надання та реалізації правової допомоги.

Відмітимо, що в представленому дослідженні нами використовується саме категорія «засади», а не «принципи» $з$ декількох причин. По-перше, при формулюванні принципів кримінального процесу, в більшості випадків, на сторінках фахової літератури, так і у позиціях окремих учених-правознавців, оперують саме категорією «засади». Зокрема, проаналізувавши декілька десятків джерел, до такого висновку доходить В.В. Навроцька в дослідженні, що присвячено засаді диспозитивності й особливостях її реалізації в кримінальному процесі України [5, с. 16]. До того ж, зауважує А.В. Дрозд, слово «принцип» має іншомовне походження [8, c. 46]. По-друге, чинне національне законодавство, хоч і використовує категорію «принципи», в більшості випадків акцентує на категорії «засади». Зокрема, в ст. 129 Основного Закону України мова йде про основні засади судочинства [9]. А в ст. 7 Кримінального процесуального кодексу України наводяться основні засади кримінального провадження [10]. 3 огляду на що, нами при позначенні основоположного керівного підгрунтя надання та реалізації правової допомоги також використовується категорія «засади».

Як було зазначено вище, сутність досліджуваної категорії може бути розкрито через аналіз категорії «принцип», яка використовується 3 давніх часів. Зокрема, з точки зору етимології, слово принцип походить 3 латинської мови від «principium», що в буквальному сенсі на українську мову може бути перекладено як начало або ж основа $[11$, с. 298]. Як цілком слушно було зауважено в цьому контексті, категорія «принцип» пройшла значний історичний шлях від повного її сприйняття із об'єктивного аспекту до їі суб’єктивного розуміння. При цьому в усі часи «принципом» позначалося дещо важливе, першооснова наявних у суспільстві явищ [12, c. 89]. В юридичній науці сутність категорії «принцип», так само як і заса- 
да, в більшості випадків розкривається майже однаково. Наявність певних відмінностей може обумовлюватися предметом наукового дослідження.

Так, наприклад, сутність вказаної категорії розкривають як: основні засади, вихідні ідеї, що характеризуються універсальністю, загальною значущістю, вищою імперативністю і відображають суттєві положення теорії, вчення, науки, системи внутрішнього та міжнародного права, політичної, державної чи громадської організації [13, с. 110]; основне, найзагальніше, вихідне положення, засіб, правило, що визначає природу та соціальну сутність явища, його спрямованість і найсуттєвіші властивості [14, c. 17]; об'єктивно властиві праву відправні начала, незаперечні вимоги (позитивні зобов'язання), які ставляться до учасників суспільних відносин із метою гармонічного поєднання індивідуальних, групових і громадських інтересів [15, с. 110]; засадничі ідеї права, які визначають зміст і спрямованість його норм та характеризуються системністю, взаємоузгодженістю, загальнообов'язковістю, універсальністю, стабільністю, предметною визначеністю, загальнозначущістю й регулятивністю [16, с. 42]; керівна ідея, базове та визначальне перше положення; основне правило поведінки; центральне поняття; основа системи [17, с. 74-75].

3 урахуванням наведених позицій під засадами надання та реалізації правової допомоги слід розуміти закріплену в приписах чинного національного законодавства сукупність правових положень, на основі яких уповноважені суб'єкти надають правову допомогу, що в подальшому реалізується в межах функціонування відповідних суспільних відносин. Більш глибокому розумінню сутності засад надання та реалізації правової допомоги має сприяти наведення їх переліку й здійснення аналізу окремих з них. При цьому слід відмітити той факт, що на сьогодні можна назвати доволі значну кількість засад надання та реалізації правової допомоги, з огляду на що їх слід піддати науковій класифікації.

У загальному значенні під класифікацією прийнято розуміти систему розподілу предметів, явищ або понять на класи, групи тощо за спільними ознаками, властивостями [1, с. 544]. При цьому класифікація може здійснюватись за різними ознаками (підставами), тобто так званими критеріями класифікації, під якими прийнято розуміти певні риси або ж особливості того чи іншого об'єкта, на підставі яких можливе його об'єднання в певні класифікаційні групи, визначення як спільних, так і відмінних ознак кожної з них $[18$, с. 275]. Іншими словами, класифікація - це властивості об'єкта, поставлені в функціональний зв'язок з його положенням у певній системі [19, с. 115]. Критерії класифікації засад надання та реалізації правової допомоги можуть бути сформовані з огляду на значну кількість аспектів: сфери суспільних відносин; правових засад їх функціонування; суб'єктного складу; процесуальної стадії тощо. А тому вважаємо за необхідне обрати найбільш універсальний критерій класифікації засад надання й реалізації правової допомоги, який би вказував як на загальне значення даної інституції, так і на особливості її функціонування в межах кримінального процесу України.

Більшість учених-правознавців в якості найбільш універсального критерія класифікації засад (принципів) функціонування відповідних суспільних відносин обирають сферу поширення таких засад. Саме даний 
критерій класифікації вказує на основні ознаки відповідної засади, зокрема, на те, в яких галузях права вона може бути застосована, на їі походження [20, с. 209]. За таким критерієм засади надання та реалізації правової допомоги можуть бути згруповані на загальноправові, міжгалузеві та галузеві.

Висновки. Отже, під засадами надання та реалізації правової допомоги слід розуміти закріплену в приписах чинного національного законодавства сукупність правових положень, на основі яких уповноважені суб'єкти надають правову допомогу, що в подальшому реалізується в межах функціонування відповідних суспільних відносин. Класифікувати вказані засади доцільно в залежності від сфери їх поширення.

\section{СПИСОК ВИКОРИСТАНИХ ДЖЕРЕЛ}

1. Великий тлумачний словник сучасної української мови (з дод., допов. та CD) / уклад. і голов. ред. В.Т. Бусел. К.; Ірпінь: ВТФ «Перун», 2009. $1736 \mathrm{c}$.

2. Хотинська 0.3. Обов'язковість судових рішень як конституційна засада судочинства України: дис. ... кандидата юрид. наук: спец. 12.00.10. Київ, 2006. 195 с.

3. Велика українська юридична енциклопедія: у 20 т. Харків: Право, 2016. Т. 5: Адміністративне право / редкол.: Ю. П. Битяк (голова) та ін.; Нац. акад. прав. Наук України; Ін-т держави і права ім. В.М. Корецького НАН України; Нац. юрид. ун-т ім. Ярослава Мудрого. 2020. 960 с.

4. Макаркин А.И. Состязательность на предварительном следствии / Науч. ред. докт. юрид. наук, проф. В. Вандышев. СПб.: Изд-во «Юридический центр Пресс», 2004. 265 с.

5. Навроцька В.В. Засада диспозитивності та іï реалізація в кримінальному процесі України: дис. ... кандидата юрид. наук: спец. 12.00.09. Львів, 2007. 256 с.

6. Пчелін В.Б. Сутність нормативно-правового регулювання організації адміністративного судочинства України. Науковий вісник публічного та приватного права. 2017. Вип. 6. Т. 2. С. 106-109.

7. Пчелін В.Б. Організація адміністративного судочинства України: правові засади: монографія. Харків: У справи, 2017. 488 с.

8. Дрозд А.В. Забезпечення недоторканності права власності в кримінальному провадженні: дис. ... кандидата юрид. наук: спец. 12.00.09. Харків, 2019. 241 с.

9. Конституція України: закон України від 28.06.1996 № 254к/96-ВР. Відомості Верховної Ради України. 1996. № 30. Ст. 141.

10. Кримінальний процесуальний кодекс України: закон України від 13.04.2012 № 4651-VI. Відомості Верховної Ради України. 2013. № 9-10. Стор. 474. Стаття 88.

11 Сучасна правова енциклопедія / за заг. ред. О.В. Зайчука; Ін-т законодавства Верховної Ради України. 2-ге вид., перероб. і допов. К.: Юрінком Інтер, 2013. 408 с.

12. Пчелін В.Б. Поняття та значення принципів організації адміністративного судочинства. Jurnalul juridic national: teorie şi practică. 2016. № 4 (20). С. 88-93. 
13. Юридична енциклопедія: В 6 т. / Редкол.: Ю.С. Шемшученко (голова редкол.) та ін. К.: «Укр. енцикл.», 1998. Т. 5: П-С. 2003. 736 с.

14. Колодій А.М. Принципи права України: монографія. К.: Юрінком Інтер, 1998. 208 с.

15. Скакун О.Ф. Теорія держави і права: [підручник] / [пер. з рос.]. Х.: Консум, 2006. 656 с.

16. Старчук О.В. Щодо поняття принцип права. Часопис Київського університету права. 2012. № 2. С. 40-43.

17. Іншин M.I. Правове регулювання службово-трудової діяльності державних службовців як особливої категорії зайнятого населення України: навчальний посібник. Харків: Вид-во «ФІНН», 2010. 672 с.

18. Музичук О.М. Контроль за діяльністю правоохоронних органів в Україні: монографія. Х.: Харк. нац. ун-т внутр. справ, 2010.654 с.

19. Юридична енциклопедія: В 6 т. / Редкол.: Ю.С. Шемшученко (голова редкол.) та ін. К.: «Укр. енцикл.», 1998. Т. 3: К-М. К.: Вид-во «Юридична думка», 2001. 792 с.

20. Пчелін В.Б. Класифікація принципів адміністративного судочинства України в залежності від сфери їх поширення. Пріоритетні проблеми юридичної науки: сучасний стан та перспективи вдосконалення: Матеріали міжнародної науково-практичної конференції (м. Київ, 18-19 липня 2015 р.). К.: «Науково-дослідний інститут публічного права», 2015. С. 209211.

\section{O. Martovytska}

\section{THE CONCEPT AND CRITERIA FOR CLASSIFYING THE PRINCIPLES OF PROVIDING AND IMPLEMENTING LEGAL AID}

The relevance of the article is that the proper provision of legal assistance and further effective implementation of its individual procedures directly depends on the completeness and quality of determining the guiding principles of the functioning of this area of public relations. It is the principles of providing and implementing legal aid that have a decisive influence on the further development of these public relations, as their non-compliance or violation may call into question the legality and validity of final procedural decisions. In the article, it has been emphasized the need to clarify the essence and criteria for classifying the principles of providing and implementing legal aid, taking into account both scientific developments and regulations in order to identify theoretical and applied problems of the institute of professional legal assistance in criminal proceedings in Ukraine. It has been emphasized that the principles of providing and implementing legal aid have a decisive influence on the further development of these public relations, as their non-compliance or violation may call into question the legality and validity of final procedural decisions. The conceptual and categorical apparatus used in the presented research has been specified. It has been found that the use of a narrow approach to defining the essence of the category "principle" is relevant, in this case - their identification with the category "principle". It has been proposed to understand the principles of providing and implementing legal assistance as a set of legal provisions enshrined in the provisions of current national legislation, 
on the basis of which authorized entities provide legal assistance, which is then implemented within the relevant public relations. It has been noted that today it is possible to name a fairly large number of principles for the provision and implementation of legal aid, given that they should be subjected to scientific classification. The criteria for the classification of the principles of providing and implementing legal aid can be formed in view of a significant number of aspects: the sphere of public relations; legal bases of their functioning; subject composition; procedural stage, etc. It has been proposed to choose the most universal criterion for classifying the principles of providing and implementing legal aid, which would indicate both the general importance of this institution and the peculiarities of its functioning within the criminal process of Ukraine.

Keywords: principles, foundations, legal aid, provision, implementation, classification. 